\title{
On The Churches Of North Bedfordshire and The Neighbouring Portion Of Northamptonshire
}

the Rev. A. J. Foster M.A.

To cite this article: the Rev. A. J. Foster M.A. (1882) On The Churches Of North Bedfordshire and The Neighbouring Portion Of Northamptonshire, Archaeological Journal, 39:1, 83-87, DOI: 10.1080/00665983.1882.10852026

To link to this article: http://dx.doi.org/10.1080/00665983.1882.10852026

里 Published online: 14 Jul 2014.

Submit your article to this journal 지

Q View related articles $\sqsubset$ 


\section{ON THE CHURCHES OF NORTH BEDFORDSHIRE AND THE NEIGHBOURING PORTION OF NORTHAMPTONSHIRE. ${ }^{\prime}$}

By the Rev. A. J. FOSTER, M.A.

Bedfordshire is divided geologically into three different belts running across the country from east to west, and the ecclesiastical architecture of the county follows these divisions, each separate division or belt having its own particular style of architecture. To the south we have the chalk downs of Dunstable, in the centre are the sandstone hills which run from Sandy to Brickhill right across the county, and the northern division which borders on Northamptonshire is a high flat table land between the Ouse and the Nene. Taking the ecclesiastical architecture in the same order, we find, first in the south that many of the churches on the chalk downs have the walls panelled checkerwise with the flint stones of the locality inserted in the mortar, a peculiarity found also in Sussex and Hampshire. Secondly, in the central belt we have many splendid churches built of the local sandstone. Thirdly, in the north, as there are no quarries on the spot, we find that the churches are built of imported limestone, brought probably from the quarries of Barnack to the north, or those of Totternhoe to the south. ${ }^{2}$ It is the ecclesiststical architecture of this portion of the county with that of the adjucent parts of Northamptonshire which forms the subject of this paper.

This border land of the two counties is for the most part a thinly populated and wild clay upland, forming in Bedfordshire a part of the great line of woods which once stretched across this part of the country. Many of these woods still remain and the roads which run between them are mostly soft lanes impassable in the winter except on foot or on horseback. The villages contained in the district are, on the Bedfordshire side, few and small, and the bulk of the population is to be found on the northern side by the banks of the Nene in Northamptonshire. This Nene valley was an important frontier in the time of the Roman occupation, and the flourishing towns and villages in the neighbourhood are the modern representatives of the Roman camps and stations which once lined the right bank of the Nene. Even to the present day an important local industry, the shoemaking trade, keeps the Northamptonshire villages populous, while the Bedfordshire villages are purely agricultural.

This being the case it may be assumed that the Northamptonshire parishes have always been the most wealthy, and, therefore, it is not surprising to find that the Northamptonshire churches were for the most part rebuilt in Early English or Decorated times, while the smaller Bedfordshire churches exhibit architectural features of all dates, the

1 Read in the Arckitectural Section at the Bedford Meeting, July 29, 1881.

2 Introduction to the Archrological
Topography of Beds. Royal Archro. logical Institute. 
result, I conclude, of paucity of population and poverty which prevented any complete rebuilding and enlargement. It is in Bedfordshire accordingly that we must look for all early examples of architecture, but where the dates are the same we find no local peculiarities which distinguish North Bedfordshire from Northamptonshire churches. There is much greater difference of style between the churches of the three divisions of Ijedfordshire of which I spoke just now, than there is between those of the northern division and Northamptonshire, for in the district which we are considering, there is a strong family resemblance in all churches which are of about the same date, especially in the matter of spires. Where the buildings are of the same clate, it is only in the richness of work and in the magnificence of the examples that Northamptonshire cluurches cliffer from those of North Bedfordshire, it is in short a difference of quality and not of principle.

And so, as Northamptonshire churches have been rebuilt, we must look for all examples of early work, whether Saxon or Norman, on the Bedfordshire sicle of the border. There we have Saxon work at St. Peter's, Bedford, and at Clapham, both situated on the Ouse to the south, and perhaps at Knotting which is in the centre of the district described. When we look over the border, however, we find no Saxon work in the Nene valley. To find examples of this style in Northamptonshire we must go further into the county, to Earl's Barton, Barnack, Brigstock, and Brixworth, and in the towers of the two first-named churches we have the most splendid examples of our earliest ecclesiastical architecture to be found, perhaps, in the whole country. It is on account, cloubtless, of their size and magnificence that these towers were preserved when Northamptonshire churches were rebuilt in later times. The Bedfordshire church of Clapham, interesting though it is as a specimen of early tower building, cannot be compared in variety and style with Earl's Barton. It is very probable that if Clapham had been in Northamptonshire its rude tower would have given place to an Early English or Decorated steeple.

When we pass on to Norman work we find the same facts. As a rule, Norman architecture has disappeared from the valley of the Nene, but still exists in North Bedfordshire, as at Farnish, Poddington, Knotting, Pertenhall, and Thurleigh. These are all small and remote villages whose inhabitants were unable, I suppose, to rebuild their churches entirely, and therefore left traces of Norman work behind as they enlarged the buildings.

In Early English and Decorated examples Bedfordshire comes far behind Northamptonshire. W We may seek in vain in the former county for such a glorious line of Churches as that which stretches from parish to parish in an unbroken line along the south bank of the Nene, and comprises Strixton, Wollaston (the tower and spire only remaining unfortunately), Irchester, Rushden, Higham Ferrers, Stanwick, Raunds, and Hargrave, all of them splendid examples of Early English and Decorated work. There is very little earlier work to be found in any of

1 I have omitted any reference to the Early English and Decorated Church of Felmersham, as this magnificent example though in North Bedfordshire stands on the right bank of the Ouse, and I have taken that river as the geographical boundary of my subject. For the same reason, I have not referred to the undoubted Saxon work to be found at Stevington, 
these churches; Irchester alone can exhibit some traces of Norman; but in North Bedfordshire, with three exceptions, all the churches are of mixed character. The first of these exceptions is Wymington, a unique and perfect specimen of Late Decorated, apparently all built at one time and unaltered. There is something continental in its appearance, which causes it to differ from other specimens of Decorated work in the neighbourhood. This is explained by the fact that it was built by John Curteys, mayor of the Staple at Calais, who lies buried beneath a brass to the south of the chancel. The founder's residence abroad probably accounts for the foreign style of the architecture. The second exception is Yelden: "a perfect specimen of Decorated work with but little alteration." The third does not belong to this period, but is the Perpendicular Church of Odell, an excellent example and all built in one style. Of the other churches of North Bedfordshire, it has been said :1 "In fact, to find an entire church belonging to one period is not the rule but the exception. Hardly any which we enter but contains portions of two-frequently three-and sometimes four distinct styles. Take, for instance, Poddington ; there are Early English pier arches and south chancel wall, Decorated chancel arch and western arch, and Perpendicular clerestory and spire. Thurleigh has Norman tower, Decorated chancel and pier arches, and Perpendicular clerestory and aisles. Tillbrook has Transitional pier arches, Early English north wall, Decorated chancel arch, and Perpendicular chancel and south wall of nave." But it is on account of their mixed character that the Bedfordshire churches are interesting from an archæological point of view; and we may hunt in vain amongst the neighbouring Northamptonshire churches for similar store-houses of different styles.

There is, however, one point in which we can compare the churches of the two districts more directly-that is, in the matter of spires. Whichever side of the borcler we visit, we cannot fail to remember that we are in the Midland counties, and therefore in the land of spires, for the tower unclowned is in both counties the exception. But here, again, Bedfordshire comes behind Northamptonshire; though not to such an extent, for some of the spires of the former county are very noteworthy. They are, however, of rather later date than those of Northamptonshire, which are Early English and Decorated; while those of Bedfordshire are, for the most part, Perpendicular. The broach of Sonldrop is the only Early English spire, and the foreign-looking spire of Wymington with its open tracery, pedimental canopies, and richly crocketed angles is Late Decorated. The short broach of Yelden is an early example of the same style. No one of these will bear comparison with the splendid Decorated spire of Higham Ferrers on the Northamptonshire side; but if we pass on to those of later date we shall find that the Perpendicular spires of Sharnbrook, a most striking example, and of Little Staughton, Tillbrook, Keysoe, Pertenhall, Colmworth, Harrold and Poddington may rank with those of Northamptonshire.

Let us compare some of the spires of the two connties together. We will begin with Irchester, in Northamptonshire, and compare it with a Bedfordshire spire-that of Pertenhall. They are both broached and without parapets and pinnacles. Then we have towers with parapets

1 "On the churches of North Bedfordshire," by the liev. C. Airuy; Papers of

Associated Architectural Societies. 
and plain spires, as at the two Bedfordshire churches of Little Stanghton and Tillbrook; very plain spires they are, with only two tiers of lights. Then we come to a third group-that in which the towers have pinnacles and sometimes parapets as well. In some of the Bedfordshire churches, however, the pinnacles have apparently never been completed; and only the stumps appear, as at Sharnbrook and Poddington. Next where we have pinnacles without buttresses we may compare Wollaston, in Northamptonshire, and Keysoe in Bedfordshire. And again, we may compare the towers and spires of the Bedfordshire churches of Wymington and Harrold with Higham Ferrers in Northamptonshire. This last-mentioned church contains in its tower and spire all the peculiarities of the groups which we have mentioned. It has the parapets of one, the pinnacles of another, the buttresses of a third, and the cornice under the parapet, and angle crockets of another group.

Bedfordshire churches have not been quite so much "restored" as those in Northamptonshire; and consequently, we find more remains of woodwork in the older and more remote churches of the first-named county, especially in the matter of rood-screens and bench ends. In Northamptonshire such work has generally altogether disappeared, or else has been worked up into other forms in most extraordinary ways, as at Irchester, where portions of the tracery of the rood screen appear as the balustrade of the modern pulpit stairs. Indeed, in the matter of rood-screens, Bedfordshire is very rich, as at Deane, Eaton Socon, Bolnhurst, Sharnbrook, Oakley, Pertenhall, Roxton, and Tillbrook. The last-mentioned is very interesting, as still surmounted by its rool-loft witli its balusters, and many of the others have fragments of the original colour and gilding. Wo find also many fine specimens of rich roof carving with remains of colour, especially at Deane and Kieysoe. The same remarks apply to stained glass, some fragments of which exist in Bedfordshire, while they are not to be found in Northamptonshire.

Altogether we see that there is a great similarity between the churches on each side of the border where they are of the same style, though the Northamptonshire churches are the more magnificent. The North Bedfordshire churches resemble those of the bordering part of Northamptonshire much more than they do those in the other districts of the county. For instance, the rooms over porches, sometimes called priests' chambers and sometimes schoolrooms, for their use does not seem to have been fixed with certainty, which are common enough in the middle district of Bedfordshire, are not to be found in the north any more than they are to be discovered in Northamptonshire. And again, nearly every church in the north has a spire, but spires are few and far between in the central and southern districts.

Not only have the Northamptonshire churches been more generally rebuilt than those in Bedfordshire, but it must also be observed that there is a richness of detail and ormament in the Northamptonshire churches which is not to be found in the poorer buildings of Bedfordshire, the result, as I have already suggested, of the comparative wealth and poverty of the two districts. Indeed, such a rich storehouse is Northamptonshire, that Rickman has drawn a great quantity of his examples from that county; and all but one of the line of Nene Valley churches which I have mentioned, consisting of Strixton, Irchester, Rushden, Frigham Ferrers, Stanwick, Raunds, and Hargrave, are laid under contribution to a considerable extent. 
Strixton is noticed for its simple and graceful west front, with its lancet and quatrefoil windows, and set of quatrefoil panels. Irchester contributes one of its spire lights and its cornice. Rushden provides its Decorated west porch and windows; with the section of a pier moulding, elaborate cornice, carved roof, inverted strainer arch known as the "Bochar" arch, and screens, all of the Perpendicular period. From Higham Ferrers we have a drawing of the Early English west porch, which may well compare in design and execution with the entrances of some of our monastic chapter-houses, and a section of the deeplycut moulding and a portion of the diaper work of the same porch. From Stanwick he gives us the base of the south doorway, a "general or containing" capital, a corbel table from the tower, a sedile, and a beautiful window, all of Early English date. Raunds furnishes an example of the early method of forming cusps, the moulding of the west porch, a delicate trefoil sunk panel, and the beautiful west window, all of Early English work; its east window of rather later date; and some arch mouldings, and the nave roof, both of Decorated times. Hargrave supplies a quatrefoil window of Early English date; and in addition to this list there are many other references to these churches which are unaccompanied by engravings. When, however, we turn to Bedfordshire, we find that Rickman only refers to one example from the Northern part of that county, the Saxon tower of Clapham, "principally remarkable," he says, "for the extreme simplicity and rudeness of its construction."

And, indeed, we cannot wonder at Rickman's selection when we look at the extreme simplicity and plainness of the Early English and Decorated work in North Bedfordshire in such specimens as Knotting chancel, Sharnbrook north doorway, Sonldrop tower and spire, Poddington chancel, and even Yelden and Wymington, and see how little there is to be chosen as examples of the best work of these times, with the Nene valley churches so close at hand. Compare for instance the Transitional west point of Knotting, now hidden by a later tower, with the graceful and beautiful west front of Strixton. Knotting is apparently of an earlier date, but the idea of the arch and the circular window above it is the same in both designs, though rude in the Bedfordshire church, and finished with exquisite taste in that of Northamptonshire. In the same way if we were to go through the other examples of Early English and Decorated in the two groups of churches which we are considering, we should find the same want of detail and finish in the Bedfordshire churches on comparing them with those of the other county.

But, in conclusion, as we pass from the glorious edifices of Northamptonshire to the poorer ones of Bedfordshire, let us remember that had all our churches been restored or rebuilt in later and more advanced days, we should have lost those specimens of early work which now interest us in so many of our country churches. The old men of Bedfordshire did what they could. If they could not equal the efforts of their neighbours across the border, they were at least content to go on little by little, adding a tower here or a spire there, an aisle to one church, a chancel to another ; and we therefore owe them a debt of gratitude because, by their very struggles against adverse circumstances, they have loft us examples and specimens, valuable in these days for local, as well as archæolo. gical reasons, 